\title{
Effect of Management Maturity Levels on Inter-organizational Management in Value Chain Relations*
}

\author{
Jaewook Kim \\ Hiroshima University, Hiroshima, Japan \\ Takayuki Asada \\ Ritsumeikan University, Osaka, Japan \\ Hirohisa Hirai \\ Takasaki City University of Economics, Gunma, Japan
}

\begin{abstract}
This paper explains the current state of management control problems in inter-organizational relationships. There is a growing consensus that having cooperative relations with other organizations, building strategic supply chain relations, and establishing appropriate subsidiary-parent company relations are major components of a competitive strategy to increase organizational productivity and profitability. In this regard, we present samples collected from 60 Japanese companies, and provide a case study on the use of inter-organizational management control systems (MCSs) by a large Japanese manufacturing company. The findings show how a company can design its organizational structure in order to realize its strategies and achieve its goals. Further, the case study shows the importance of management control factors that are associated with activities in inter-organizational value chain relations. In particular, high management maturity in information management, cultural management, and structural management are identified as key factors for the integration of strategy with sustainable inter-organizational management.
\end{abstract}

Keywords: inter-organizational management, maturity analysis, case study

\section{Introduction}

The relationship between organizational collaborations and networks is an indispensable part of today's business world, and its management has been a major component of competitive strategy to increase organizational productivity and profitability. However, not much is known about the management control processes that integrate strategies with sustainability in inter-organizational relations.

There is a growing consensus that having cooperative relations between different organizations and fields, building strategic supply chain management (SCM) relations, and strengthening cooperative subsidiary-parent company relations are necessary mechanisms for the sustainable growth of highly competitive companies

\footnotetext{
* Acknowledgements: This article was supported by Japan Society for the Promotion of Science (JSPS) KAKENHI (Grant-in-Aid for Scientific Research (B) 25285142, (C) 25380630, Grant-in-Aid for Young Scientists (B) 15K17162).

Jaewook Kim, assistant professor, Department of Management Studies, Graduate School of Social Sciences, Hiroshima University. Email: jaewookk@hiroshima-u.ac.jp.

Takayuki Asada, professor, Business Administration, Ritsumeikan University.

Hirohisa Hirai, professor, Department of Economics, Takasaki City University of Economics.
} 
(Bebbington \& Thomson, 2013; Caglio \& Ditillo, 2012; Dekker, 2003; Gond, Grubnic, Herzig, \& Moon, 2012). However, several questions arise at this point. First, a survival problem exists on how a company can develop its core competence between such relations in a rapidly changing environment. Furthermore, the management control systems (MCSs) have to be defined as frameworks that coordinate these organizational relations (Ferreira \& Otley, 2009), further global cooperation (Seal, Berry, \& Cullen, 2004), and identify the related stakeholders (Rodrigue, Magnan, \& Boulianne, 2013).

Although many organizations have tried to explain and share their strategies, plans, and outcomes using managerial-oriented reporting systems, it is a slightly different story when it comes to inter-firm relationships. Dekker (2003) indicated three issues on which collaborating firms may be concerned with: exchanging sensitive information, cost and benefits sharing, and investments appropriation problems.

An important issue is whether or not a company can design its organizational structure to gain its goals and realize its strategies (Simons, 2006; Tessiera \& Otley, 2012). Furthermore, problems such as control systems, information sharing and responsibility sharing are important factors to sustain an organization's growth, especially in inter-organizational relations (Dekker, 2003; Ding, Dekker, \& Groot, 2013). It is not enough to just understand the routines, processes, and actions between corporate organizations in inter-organizational relations for sustaining organizational relationships with continuous growth.

From this perspective, this paper discusses the current state and the problems between corporate organizations that the MCS needs to overcome from the results of a case study and a sample survey. This research contributes to the literature in the following respects. First, we show that it is important for organizations to employ MCS as a strategic driver. Second, this study presents an opportunity to build a management control framework more effective with inter-organizational relations.

The rest of the paper is organized as follows. Section 2 describes our research method. Section 3 presents some data examples collected through mailed questionnaire-based surveys. Section 4 provides a case study on the use of inter-organizational MCSs by a large Japanese manufacturing company. Section 5 concludes the paper and discusses some possible aspects for a future research.

\section{Research Method}

This paper attempts to explain the current state of management control problems in inter-organizational relationships. For the purpose of our research and to review the state of inter-organizational relationships, we introduce a case study of a Japanese company and provide some data collected from Japanese manufacturing companies. Our case study shows how a global company manages its value chains in a rapidly changing environment. The data for this study were collected for 2009 and 2013 from the Daikin Industries Ltd. (Japan), Daikin Europe N.V., and Daikin Industries Czech Republic. Interviews and discussions were held with the vice president director of manufacturing in Europe, vice president director of sales, accounting staff (Japan), and senior director of the company (Japan). In addition to interviewing, our other data sources included the company presentation slides, annual reports, and publications.

We also present some samples collected from 60 Japanese companies. To review the inter-organizational management in Japanese manufacturing, we collected data from 1,021 companies of the TSEM (Tokyo Stock Exchange Market) First Section through a mailed questionnaire-based survey. 


\section{Inter-organizational Management in Japanese Manufacturing: The Results of Our Questionnaire and Some Analysis of Japanese MCS}

To review the inter-organizational management in Japanese manufacturing, we collected data from 1,021 companies of the TSEM First Section through a mailed questionnaire-based survey. We used the data collected from 60 samples.

\section{Capital Ties and the Degree of Development, Production, and Sales Effects}

Our survey included questions about influences on sales, production, and R\&D of companies having capital ties during the past five years. About $80 \%$ of the respondents showed that they were influenced by company capital ties by less than $10 \%$ or $0 \%$ only.

\section{Degree of Decentralization and Flexibility}

With regard to decentralization or flexibility of sales destinations and suppliers (product sources), about half of the respondents indicated no decentralization and flexibility with regard to sales destinations (that is, over $80 \%$ of transactions showed continuous relations in whole sales). Half of the respondents showed that their decentralization ratio in the whole sales was less than $20 \%$. From the data, most of the respondents have stable fixed sales destinations. About $65 \%$ of the respondents have no decentralization and flexibility of product sources (suppliers). This means that more than $65 \%$ of respondents have stable fixed product sources. More than $80 \%$ of the transactions showed continuous relations in whole product sources. Less than $35 \%$ showed several routes to supply product sources.

\section{Factor of Supplier Selection}

From the data, the important factors to select suppliers are technological competencies, reliability, and financial stability. In contrast, firm size, domestic or foreign company, and matching company cultures are relatively less important factors.

\section{Agreements With Global Manufacturing Base}

Agreements with global manufacturing bases may indicate empowerment of global manufacturing bases. For reporting items and items of discussion, a detailed agreement process exists between global manufacturing bases and parent companies. However, relatively no agreement exists for monitoring and supervising the items relating to global manufacturing bases.

\section{Accountability of Global Subsidiary Company}

From the sample data, for the accountability of global subsidiaries to parent companies, the accountability for costs and expenses, sales and revenues, and returns on investments mark a higher score than that for environment management and corporate social responsibility (CSR).

\section{Inter-organizational Management at Daikin Industries Ltd.}

\section{Company Background}

Daikin is one of the global air-conditioning manufacturers with presence in Japan, Europe, North America, China, and Asia/Oceania countries, etc.. At the time of study, Daikin has been showing successful overseas businesses (over 100 billion yen) in new areas, with over $60 \%$ of sales turnover from overseas sales. During the early 2010s, following the global recession and appreciation of the yen, the company's performance declined, but, in spite of the harsh operating environment, it managed to realize a V-shaped performance recovery. 
The central strategy of Daikin's global business expansion is its emphasis on localization, meaning that its products are developed in the same environment where the company sells its products throughout the world. The company's policy appears in its global network relations. Table 1 shows the company's main production facilities. The production ratios are 100\%, 84\%, 98\%, and 90\% of MOYORIKA (within each region), respectively, in the main four markets, Japan, Europe, Asia/Oceania, and China. The basic idea behind the strategy is that its manufacturing and sales sides do not reach an out-of-stock situation anytime. Besides its advanced technologies, the company's production and sales decision-making are accurate and timely, enabling the company to achieve its successful business expansion. Moreover, the company's organizational design, decentralization policies, and inter-organization cooperation help in its effective strategy implementation too.

Table 1

Main Production Facilities

\begin{tabular}{|c|c|c|c|c|}
\hline Facility (presence) & Equity (billion) & Production start & Shareholding (\%) & Product range \\
\hline Daikin Europe N.V. (Belgium) & $¥ 7.8$ & 1973 & 100 & VRV, Daikin Altherma, Sky Air \\
\hline $\begin{array}{l}\text { Daikin Industries Czech Republic } \\
\text { (Czech Republic) }\end{array}$ & 7.6 & 2004 & 100 & Room Air \\
\hline $\begin{array}{l}\text { Daikin Device Czech Republic } \\
\text { (Czech Republic) }\end{array}$ & 9.1 & 2006 & 100 & Daikin Altherma, Sky Air \\
\hline $\begin{array}{l}\text { Daikin Industries Thailand } \\
\text { (Thailand) }\end{array}$ & 6.8 & 1990 & 100 & Room Air, VRV, Packaged/Sky Air \\
\hline $\begin{array}{l}\text { Daikin Compressors Industries } \\
\text { (Thailand) }\end{array}$ & 8.6 & 2001 & 100 & Compressors \\
\hline DIS (Shanghai, China) & 9.2 & 1995 & 87 & Room Air, VRV, Packaged/Sky Air \\
\hline DIX (Xi’an, China) & 2.9 & 1996 & 51 & Compressors \\
\hline
\end{tabular}

\section{SCM}

The company's SCM efforts are managed by its Global SCM department. The department is established for operating its processes smoothly through R\&D to products mass production. In addition, the department manages its global supply control situations including Japan, and plays a crucial role in its SCM systems operating reforms.

Before the Global SCM department was launched, the company faced numerous SCM problems. In its SCM for the global air-conditioning business environment, the department had to solve issues such as the complexity of two flows in one production plan stage (a new product development and mass production), the sudden production of old models, a high stock level for old models, and abnormal costs from safety products and parts levels. In the company, wastes occurred between divisions, because there was no centralized management control over sales planning, stock planning, and production planning. Additional action had to be taken, such as flexibility in adapting production levels, efforts for balancing stock levels, and maintaining a high customer service level to changing demands, especially in the peak season.

The role of the company's Global SCM department in its air-conditioning business is generally to integrate the management, planning, and results of the whole business. In detail, the department carried out a central role not only in conventional production planning decisions and production progresses, but also in managing plans (i.e., receipt and payment, production, parts ordering, stock planning, etc.) and results, clarifying problems, and execution. 
The basic principle of the company's global production is to develop and produce goods in the same environment of the sales market. Daikin calls this system MOYORIKA. However, in case of lack of production capacity or a total costs increase, the company considers delivering products and components from other districts' facilities or production centers. In this case, while fixed amounts of sales within a region are delivered from outside, the variable amounts of sales are produced within the nearest market places.

Table 2 gives the company's estimated SCM costs, distribution costs, taxes, and foreign exchange rates. In order to reduce its inventories through global cooperation, the company arranges its production systems so as to follow and capture demand changes. Delivering products from China and Thailand to Europe takes about 40 days. Thus, the company's production lead time becomes longer and stock risk also increases.

Table 2

SCM Costs at Daikin Europe

\begin{tabular}{|l|l|l|l|}
\hline Main distributors & Custom duties & Income taxes & $\begin{array}{l}\text { Foreign exchange rates } \\
\text { (estimates) }\end{array}$ \\
\hline Europe (Manufacturing base for Europe markets) & $\begin{array}{l}\text { Outside (2.7\% 2.2\%) } \\
\text { Inside 0\% }\end{array}$ & $\begin{array}{l}\text { Belgium 33\% } \\
\text { Czech Republic 19\% }\end{array}$ & $\begin{array}{l}150 \text { EURO/JPY } \\
5.35 \text { CZK/JPY }\end{array}$ \\
\hline $\begin{array}{l}\text { China (Manufacturing base for China markets, special } \\
\text { models for Japan markets) }\end{array}$ & $\begin{array}{l}\text { Outside 15\% } \\
\text { Inside 0\% }\end{array}$ & $25 \%+$ & 15 CHY/JPY \\
\hline Japan (Manufacturing base for Japan markets) & $\begin{array}{l}\text { Outside 0\% } \\
\text { Inside 0\% }\end{array}$ & $30 \%+$ & 115 JPY/USD \\
\hline $\begin{array}{l}\text { Thailand (Manufacturing base for Asia and Oceania, } \\
\text { global manufacturing base for room air-conditioner) }\end{array}$ & $\begin{array}{l}\text { Outside 30\% } \\
\text { Inside 5\% }\end{array}$ & $30 \%$ & 3.5 THB/JPY \\
\hline Malaysia (Manufacturing base) & $\begin{array}{l}\text { Outside 30\% } \\
\text { Inside 5\% }\end{array}$ & $28 \%$ & $33 \mathrm{M}$ USD/JPY \\
\hline
\end{tabular}

Note. Distribution costs (Thailand to Europe): Room air conditioner 8\%, Compressor 4\%; Stock costs (Europe): Room air conditioner $2 \%$, Compressor $2 \%$.

To avoid such situations, the company has made its own policy clear. When delivering from distant places, it becomes necessary to consider the problems associated with inventory stock increases and exchange risks with the tariffs. This can be avoided when production is within the market places.

For example, the company's production costs for room air conditioners in Thailand and China are almost at the same level. The production costs in Europe (the Czech Republic) are also approaching the total production cost in Thailand, which includes delivering costs.

At the time of the study, the company's sales in Europe were supplied from the Czech Republic and Thailand, 31\% of which were for residential room air-conditioning and $69 \%$ for non-residential air conditioners. Among the non-residential air conditioners, about $90 \%$ of the multi-air conditioners were for office buildings and produced at the company's Europe factory. These efforts could be achieved because of the company's decentralized production facility placed between Asia and Europe and the global, flexible integration of SCM within the value chain.

\section{Products in Europe for Europe: Daikin Europe N.V. (DENV)}

The ratio of MOYORIKA reached about 84\% for DENV. For the European market, about $84 \%$ of the products are delivered from DENV. DENV is the company's sales and manufacturing headquarter for Europe, Africa, and the Middle East areas for mainly non-residential and office buildings equipment. Later, in 2004, the company established a production plant in the Czech Republic and the production capacity of DENV expanded. The plant in the Czech Republic mainly produces relatively low value-added room air-conditioning compared with those for business uses and shares its roles and functions with DENV, the mother factory. 
The flow from production to sales is as follows: first, a stock plan is drawn by the supply center of DENV; second, stocks are purchased from the affiliated company's factories in Japan, Thailand, and Italy; and finally, the product flows from the sales division in DENV to 15 sales companies, that is, basically one sales company for each country in Europe and one agency in each country. Moreover, as for parts, they are transferred from China and Thailand owing to the cost advantage and the difficulty of local procurement.

One of the main problems for globalized corporate organizations is how to manage their supply-demand problems in inter-organizational relationships and information management.

For example, DENV needs to manage its value chain from China to DENV, to the sales company in each country, to the local agency, and to the wholesalers. In order to support their value chain management efforts, they need to share sensitive information and resources within the value chain for their sustainable growth.

In fact, DENV's problem in SCM is the lack of a unified management system for planning and coordinating their sales, stock, and production between divisions. For example, flexibility in adapting production levels to suit the changing market demands and balancing the stock levels on hand were continuous challenges in their SCM effort.

DENV's supply center played a key role in the flexible integration of its management system and SCM. Its efforts are considered one of the key factors that led to the early business recovery following the 2008 global recession. As already mentioned, one of the DENV's problems was how to collect and share information quickly through their value chains, and adjust their production and stock levels.

To solve this problem, DENV decided to change the organizational position of their supply center. The center was separated from the sales department and placed under the president's direct control so that the function of the supply center could be strengthened. From the changes in the supply center's role, communications between organizations could be made more smoothly, and more original supply adjustment judgments became possible from the neutral viewpoint of the sales department and the production head office.

A formal supplier meeting is held once a month, and the demands are estimated and adjusted taking into account the expectations of the sales companies. In addition to formal meetings, communications take place between the production head office, sales department, supply center, and sales companies in an informal way.

Another organizational feature of the company is its strategically decentralized production systems and flexible management of SCM. The production of heating products has been strengthened in Europe, which functions as a global key center, whereas the production of low-cost model products has been strengthened strategically in China, which functions as a base of a global key center. In addition, decentralized production systems have been implemented in Europe as well. While relatively high value-added products for industrial use are produced at the company's Belgium factory, low value-added room air conditioners are made at its Czech Republic factory. This is called decentralized production system. However, the low value-added products of DENV's new up-and-coming market are imported from China and Malaysia.

While the company is actively engaged in policy in accordance with MOYORIKA, its costs side is also being considered and decentralized production takes place at the global level as well. Following these efforts, manufacturing is closely linked to the market, and in parallel, the promotion of decentralized production presents the company with opportunities, flexible correspondence with the market, and decreasing stock risks, and decreases the impact of changes in foreign exchange rates on its financial performance. 


\section{Conclusion}

\section{Conclusions and Implications}

Organizational collaborations are one of the most important parts of today's business environment. In this context, a consensus about building strategic SCM relations and strengthening cooperative subsidiary-parent company relations is increasing. From this perspective, we explore the current state of inter-organizational management in value chain relations and the associated problems.

Our findings show how a company can design its organizational structure in order to realize its strategies and achieve its goals. We also provide evidence of the management maturity effect on inter-organizational management. With regard to the case company, we find that an MCS is an important factor that is associated with inter-organizational relations. Further, the company's practices, such as sharing information with organizations, and its organizational culture or structure, which makes information sharing possible, are identified as key factors in order to integrate strategy with sustainable inter-organizational management. Thus, because of the case company's high management maturity with regard to information management, cultural management, and structural management, it can manage and control its value chains effectively.

Our findings suggest possible areas for further research. For example, from our survey, we find that capital ties are a minor consideration of production and sales in inter-organizational management. When a company tries to sustain its inter-organizational relations, issues on quality, cost, and delivery may be of greater interest than capital ties. Moreover, the case company, which operates in the air-conditioning industry, demonstrates stable fixed network relations in accordance with the sample's results. With regard to empowerment, comparatively few agreements exist within the area of relations. In addition, there is comparatively low accountability for environmental management and CSR between global subsidiaries and their parent companies. In this regard, decentralization, flexibility, and empowerment problems are thought to be important in inter-organizational management.

This study has limitations. Besides the theoretical problem, further analysis of the collected data is necessary. The current analysis does not provide sufficient evidence of a full-fledged mechanism for an MCS and its financial benefits. Further, although we suggest possible interpretations, the evidence remains unclear in terms of the different results from the sample survey with the case company. However, despite this, our study provides possible avenues for further research in this field. By showing the importance of management control factors, we present an opportunity to build a management control framework that is more effective in the context of inter-organizational relations. In addition, we contribute to the literature by providing a new perspective of an MCS as a strategic driver.

\section{References}

Bebbington, J., \& Thomson, I. (2013). Sustainable development, management and accounting: Boundary crossing. Management Accounting Research, 24(4), 277-283.

Caglio, A., \& Ditillo, A. (2012). Opening the black box of management accounting information exchanges in buyer-supplier relationships. Management Accounting Research, 23(2), 61-78.

Dekker, H. C. (2003). Value chain analysis in interfirm relationships: A field study. Management Accounting Research, 14(1), $1-23$.

Ding, R., Dekker, H. C., \& Groot, T. (2013). Risk, partner selection and contractual control in interfirm relationships. Management Accounting Research, 24(2), 140-155. 
Ferreira, A., \& Otley, D. (2009). The design and use of performance management systems: An extended framework for analysis. Management Accounting Research, 20(4), 263-282.

Gond, J. P., Grubnic, S., Herzig, C., \& Moon, J. (2012). Configuring management control systems: Theorizing the integration of strategy and sustainability. Management Accounting Research, 23(3), 205-223.

Rodrigue, M., Magnan, M., \& Boulianne, E. (2013). Stakeholders' influence on environmental strategy and performance indicators: A managerial perspective. Management Accounting Research, 24(4), 301-316.

Seal, W., Berry, A., \& Cullen, J. (2004). Disembedding the supply chain: Institutionalized reflexivity and inter-firm accounting. Accounting, Organizations and Society, 29(1), 73-92.

Simons, R. (2006). Levers of organization design: How managers use accountability systems for greater performance and commitment. Boston: Harvard Business School Press.

Tessiera, S., \& Otley, D. (2012). A conceptual development of Simons' levers of control framework. Management Accounting Research, 23(3), 171-185. 